\title{
Assessment of nutritional status of children of age 5-14 years in covered rural area of Private Medical College, Kanpur
}

\author{
Som Nath', Anju Gahlot ${ }^{2 *}$, Pravin K Sinha ${ }^{3}$, Manjusha Nath ${ }^{4}$ \\ ${ }^{\mathbf{1}}$ Associate Professor, ${ }^{2}$ Professor, ${ }^{\mathbf{3}, \mathbf{4}}$ Tutor, ${ }^{\mathbf{1 - 3}}$ Dept. of Community Medicine, ${ }^{\mathbf{4}}$ Dept. of Pharmacology, Rama Medical College \& Research \\ Centre, Kanpur, Uttar Pradesh, India
}

\begin{abstract}
Introduction: Globally, there were 821 million undernourished people in 2017 (11\% of the total population). Under nutrition is more common in developing countries. In India, even today, after six decades of independence and despite various initiatives, the condition of undernourished children remains a cause of concern in the country. Magnitude of the problem become clearer by our research on assessment of nutritional status of children aged 5-14 years in rural areas of Kanpur.

Materials and Methods: This is a cross sectional study conducted among 410 randomly selected children of age 5 to 14 years in the rural field areas of Rama medical College \& Research Centre. Sample size 410 was calculated by using statistical formula $\mathrm{n} \geq 4 \mathrm{p} \mathrm{q} / \mathrm{L}$. Data was collected and analyzed by using appropriate statistical software and tools.

Results: The education of the parents of study subjects and their nutritional status was found to be statistically significant (X2=15.66 $\mathrm{P}=0.001)$. The association between socioeconomic class of children and their nutritional status was found to be statistically significant $(\mathrm{X} 2=10.284 \mathrm{p}=0.016)$. Under weight children were found more in Joint Family 35\%. Overall prevalence of underweight, stunting and thinness (BMI<-2SD) for age/sex among children were $27.8 \%, 22.9 \%$ and $22 \%$ respectively. Study also concluded that prevalence of under nutrition was found to be higher among females as compared to males.

Conclusion: The study shows undernourished children were found to be significantly associated with age, sex and education of the parents, socioeconomic class of the family and type of the family. It was significantly higher in females, age of puberty, children of uneducated mothers or of lower class family or belonging to joint family. Health education should be added in the school curriculum and it is needed to raise the maternal literacy particularly related to health care seeking behavior.
\end{abstract}

Keywords: Undernourished, Children of age 5-14 years, Underweight, Stunting, Thinness.

\section{Introduction}

Malnutrition in children is a common global problem; contribute in irreversible negative impact on health viz. child morbidity and mortality, ultimately affecting productivity which reduces economic growth. The World Health Organization (WHO) estimates hat malnutrition accounts for 54 percent of child mortality worldwide, ${ }^{1}$ about 1 million children. ${ }^{2}$ WHO also estimates that childhood underweight is the cause for about $35 \%$ of all deaths of children under the age of five years worldwide. ${ }^{3}$ There were 821 million undernourished people in the world in 2017 (11\% of the total population). ${ }^{4}$ This is a reduction of about 176 million people since 1990 when $23 \%$ were undernourished. ${ }^{4,5}$

Undernutrition is more common in developing countries. ${ }^{6}$ In India, even today, after six decades of independence and despite various initiatives both on the legal as well as policy and programme levels, the condition of children remains a cause of concern in the country. There are some commonly used measures for detecting malnutrition in children: ${ }^{7-9}$

\section{Stunting}

Height for age is below minus two standard deviations (-2 $\mathrm{SD})$ from the median of the reference population are considered short for their age (stunted) and are chronically malnourished.

\section{Underweight}

Weight for age is below minus $2 \mathrm{SD}$ from the median of the reference population), It takes into account both acute and chronic malnutrition. And

Wasting-extremely low weight for height below -2SD from the median of the reference population are considered thin (wasted) for their height and are acutely malnourished.). ${ }^{10}$

\section{Thinness}

(Measure of body fat) is defined as a low body mass index. Children with $\mathrm{z}$ scores $(\mathrm{BMIZ})<-2$ are considered as thin.

In India, NFHS-4 (2015-16) estimates 38\% of children under age five years as stunted (too short for their age) which signify chronic under-nutrition. The prevalence of stunting in India has decreased from $48 \%$ in 2005-06 to $38.4 \%$ in $2015-16$. Stunting is observed to be higher among children in rural areas (41\%) than urban areas (31\%). NFHS-4 results reveal that, $21 \%$ wasted and $36 \%$ of children under age five years are underweight. ${ }^{11}$

\footnotetext{
*Corresponding Author: Anju Gahlot, Dept. of Community Medicine, Rama Medical College \& Research Centre, Kanpur, Uttar Pradesh, India

Email: dranjugahlot@gmail.com

http://doi.org/10.18231/J.JJFCM.2019.037
} 
In 2010 protein-energy malnutrition resulted in 600,000 deaths down from 883,000 deaths in $1990 .^{12}$ It is obvious that there is urgent need to focus on the nutritional and overall developmental needs of children. In India, there are number of studies among under 5 years malnourished children and a number of nutritional programme running for pre-school and school going children but still nutritional status of children of age between 5-14 years is not so improved as expected. Magnitude of the problem become clearer by our research on assessment of nutritional status of children aged 5-14 years in rural areas of Kanpur.

\section{Materials and Methods}

This is a cross sectional study conducted among children of age group 5 to 14 years in the rural field areas of Rama medical College \& Research Centre in a duration of one year (Jan. to Dec.2018).Sample size is calculated by using prevalence of stunting (chronic malnutrition) among children in rural areas of Uttar Pradesh as per NFHS-4 data $^{11}$ was $48.5 \%$ and by applying the statistical formula to calculate sample size. Sample size (n)

$$
\begin{gathered}
\mathrm{n}^{3} \geq \frac{\mathrm{Z}_{1+\alpha / 2}^{2} \times \mathrm{p} \times(1-\mathrm{p})}{\mathrm{L}^{2}} \\
\mathrm{n}^{3} \geq \frac{(1.96)^{2} \times 0.485 \times 0.515}{(0.0485)^{2}}=408
\end{gathered}
$$

Where $\mathrm{p}$ is the prevalence considered as $48.5, \mathrm{~L}$ is the allowable error taken as $10 \%$ of $p$ (prevalence)... $\mathrm{Z}=$ Standard normal variable. Adjusting for the non response, the sample size was taken 410 in this study.

There are total twenty four villages in covered field area of RHTC, Rama Medical College and Research Centre, Kanpur; out of this six villages(viz. Dubiana, Bhalpura,
Mahipalpur, Kakupur, Thaliniwala, Chakabaka) were randomly selected by using computer generated random number by opting simple randomization method. $1^{\text {st }}$ house was selected purposively then every $5^{\text {th }}$ house in serial order, were visited and interviewed till our sample size of 410 children were achieved. All eligible children residing in the house were included in the study. Children or parents, who were not willing to give the consent or were seriously ill or hospitalized or were shifted / not found at the time of visits, were excluded from our present study.

Ethical clearance was taken for the study from Institutional ethical committee. A set proforma of predesigned, pre-tested semi-structured questionnaire were used for taking the interview. After taking the consent from parents, eligible children were examined physically and clinically. Anthropometric measurements viz. height, weight was taken by applying standardized techniques recommended by WHO. ${ }^{13}$ Assessment of nutritional status of children was done by calculating Weight for age, Height for Age and Body Mass Index for age and sex and using WHO growth reference standards. Data was collected and analyzed by using appropriate statistical software and tools.

Results

Table 1: Gender-wise Distribution of study children of age 5-14 years

\begin{tabular}{|c|c|c|c|}
\hline Gender & $\begin{array}{c}\text { Mean Age } \\
\text { (in years) }\end{array}$ & N (\%) & $\begin{array}{c}\text { Std. } \\
\text { Deviation }\end{array}$ \\
\hline Male & 10.54 & $226(55.12)$ & 2.66 \\
\hline Female & 9.94 & $184(44.88)$ & 2.68 \\
\hline Total & 10.27 & $410(100)$ & 2.68 \\
\hline
\end{tabular}

Table 1 depicts mean age with standard deviation of boys was $10.546 \pm 2.66$ years and mean age of girls were $9.94 \pm 2.68$ years

\begin{tabular}{|c|c|c|c|c|}
\hline \multicolumn{5}{|c|}{ Distribution of study children according to weight for age } \\
\hline & & for age & & \\
\hline \multirow[t]{2}{*}{ Gender } & Normal & Underweight & Total & \multirow[t]{2}{*}{ Chi-square Test } \\
\hline & $\mathbf{N}(\%)$ & $\mathbf{N}(\%)$ & $\mathbf{N}(\%)$ & \\
\hline Male & $163(74.8)$ & $55(25.2)$ & $218(53.2)$ & \multirow{2}{*}{$\begin{array}{c}\mathrm{X}^{2}=1.538 \\
\mathrm{P}=0.226\end{array}$} \\
\hline Female & $133(69.3)$ & $59(30.7)$ & 192(46.8) & \\
\hline Total & $296(72.2)$ & $114(27.8)$ & $410(100)$ & \\
\hline $\begin{array}{l}\text { Weight in Kg } \\
\text { Mean } \pm \text { SD }\end{array}$ & $30.95 \pm 8.37$ & $19.61 \pm 3.613$ & & \\
\hline \multicolumn{5}{|c|}{ Distribution of children according to 'Education of Father' } \\
\hline Educated & $247(74.4)$ & $85(25.6))$ & $332(81.0)$ & \multirow{2}{*}{$\begin{array}{c}\mathrm{X} 2=4.217 \\
\mathrm{df}=1 \mathrm{P}=0.049\end{array}$} \\
\hline Uneducated & $49(62.8)$ & $29(37.2)$ & $78(19.0)$ & \\
\hline Total & $296(72.2)$ & $114(27.8)$ & $410(100.0)$ & \\
\hline \multicolumn{5}{|c|}{ Distribution of children according to' Education of Mother' } \\
\hline Educated & 205(78.8) & $55(21.2)$ & $260(63.4)$ & \multirow{2}{*}{$\begin{array}{c}X 2=15.66 \\
\text { df }=1 \mathrm{P}=0.001\end{array}$} \\
\hline Uneducated & $91(60.7)$ & $59(39.3)$ & $150(36.6)$ & \\
\hline Total & $296(72.2)$ & $114(27.8)$ & $410(100.0)$ & \\
\hline \multicolumn{5}{|c|}{ Distribution of children according to 'Socioeconomic Class' } \\
\hline Upper/Upper Middle & $12(92.3)$ & $1(7.7)$ & $13(3.2)$ & $\mathrm{X} 2=10.284 \mathrm{df}=3$ \\
\hline
\end{tabular}

Table 2a: Weight for Age with Socio-demographic profile of study subjects 


\begin{tabular}{|c|c|c|c|c|}
\hline Middle & $61(81.3)$ & 14(18.7) & $75(18.3)$ & \multirow[t]{3}{*}{$\mathrm{p}=0.016$} \\
\hline Lower Middle & $129(73.3)$ & $47(26.7)$ & $176(42.9)$ & \\
\hline Lower & $94(4.4)$ & $52(35.6)$ & $146(35.6)$ & \\
\hline Total & $296(72.2)$ & $114(27.8)$ & $410(100.0)$ & \\
\hline \multicolumn{5}{|c|}{ Distribution of children according to 'Family Type' } \\
\hline Nuclear & $155(80.3)$ & $38(19.7)$ & 193(47.1) & \multirow{3}{*}{$\begin{array}{c}\text { Chi Square = } \\
11.965, \mathrm{df}=1 \\
\mathrm{p}=0.001\end{array}$} \\
\hline Joint & $141(65.0)$ & $76(35.0)$ & $217(52.9)$ & \\
\hline Total & $296(72.2)$ & $114(27.8)$ & 410(100) & \\
\hline
\end{tabular}

*Weight for age Boys / Girls (WHO 2007 reference

Table 2a depicts out of total 410 study children, male and female were 53.2\%(218), 46.8\%(192) respectively. In this Normal Weight for Age children were 72.2\%(296); Male 74.8\%(163), Female 69.3\%(133) and Underweight children were $27.8 \%(114)$; Male $25.2 \%$, Female $30.7 \%$. Mean weight for age of normal Weight children was $30.95 \pm 8.37 \mathrm{Kg}$ while mean weight for age of underweight children was $19.61 \pm 3.613 \mathrm{Kg}$.

Uneducated parents have more percentage of underweight children viz. Father 37.2\%; Mother 39.9\%. Percentage of underweight children were gradually increasing from upper to lower class viz. Upper/Upper Middle 7.7\%; Middle18.7\%, Lower Middle 26.7\%; Lower 35.6\%. Underweight children were found more in Joint Family 35\% than Nuclear Family $19.7 \%$.

Table 2b: Age-wise distribution of study children according to Weight for Age

\begin{tabular}{|c|c|c|c|c|c|c|}
\hline \multirow{3}{*}{$\begin{array}{l}\text { Age (in } \\
\text { completed } \\
\text { yrs.) }\end{array}$} & \multicolumn{6}{|c|}{ Weight for age Boys / Girls } \\
\hline & \multicolumn{2}{|c|}{ Male(n=218) } & \multicolumn{2}{|c|}{ Female(n=192) } & \multicolumn{2}{|c|}{ Total $(n=410)$} \\
\hline & $\begin{array}{l}\text { Normal } \\
\mathbf{N}(\%)\end{array}$ & $\begin{array}{c}\text { Underweight } \\
\mathbf{N}(\%)\end{array}$ & $\begin{array}{c}\text { Normal } \\
\text { N }(\%)\end{array}$ & $\begin{array}{c}\text { Underweight } \\
\mathbf{N}(\%)\end{array}$ & $\begin{array}{l}\text { Normal } \\
\mathbf{N}(\%)\end{array}$ & $\begin{array}{c}\text { Underweight } \\
\mathbf{N}(\%)\end{array}$ \\
\hline 5 & $3(75.0)$ & $1(25.0)$ & $2(66.7)$ & $1(33.3)$ & $5(71.4)$ & $2(28.6)$ \\
\hline 6 & $11(84.6)$ & $2(15.4)$ & $13(76.5)$ & $4(23.5)$ & $24(80.0)$ & $6(20.0)$ \\
\hline 7 & $27(90.0)$ & $3(10.0)$ & $26(86.7)$ & $4(13.3)$ & $53(88.3)$ & $7(11.7)$ \\
\hline 8 & $21(52.5)$ & $19(47.5)$ & $11(44.0)$ & $14(56.0)$ & $32(49.2)$ & $33(50.8)$ \\
\hline 9 & $24(82.8)$ & $5(17.2)$ & $25(78.1)$ & $7(21.9)$ & $49(80.3)$ & $12(19.7)$ \\
\hline 10 & $3(60.0)$ & $2(40.0)$ & $2(50.0)$ & $2(50.0)$ & $5(55.6)$ & $4(44.4)$ \\
\hline 11 & $4(66.7)$ & $2(33.3)$ & $7(70.0)$ & $3(30.0)$ & $11(68.8)$ & $5(31.3)$ \\
\hline 12 & $24(85.7)$ & $4(14.3)$ & $12(66.7)$ & $6(33.3)$ & $36(78.3)$ & $10(21.7)$ \\
\hline 13 & $14(70.0)$ & $6(30.0)$ & $17(56.7)$ & $13(43.3)$ & $31(62.0)$ & $19(38.0)$ \\
\hline 14 & $32(74.4)$ & $11(25.6)$ & $18(78.3)$ & $5(21.7)$ & $50(75.8)$ & $16(24.2)$ \\
\hline \multirow[t]{2}{*}{ Total } & $163(74.8)$ & $55(25.2)$ & $133(69.3)$ & $59(30.7)$ & $296(72.2)$ & $114(27.8)$ \\
\hline & \multicolumn{2}{|c|}{$\mathrm{X} 2=18.663, \mathrm{df}=9, \mathrm{p}=.028$} & \multicolumn{2}{|c|}{$\mathrm{X} 2=17.042 \mathrm{df}=9 \mathrm{p}=.045$} & \multicolumn{2}{|c|}{$\mathrm{X} 2=28.583 \mathrm{df}=9, \mathrm{P}=.001$} \\
\hline
\end{tabular}

*Weight for age Boys / Girls (WHO 2007 reference) ${ }^{14,15}$

Table2b shows among study boys, $74.8 \%$ were of normal weight for age and $25.2 \%$ were underweight for age. Maximum underweight boys were of age 8 yrs, 19(47.5\%). Underweight girls were mostly of age 8 years $56.0 \%$; 13 years, $43.3 \%$. Overall children of different age group having normal weight were $72.2 \%$ while underweight children were $27.8 \%$.

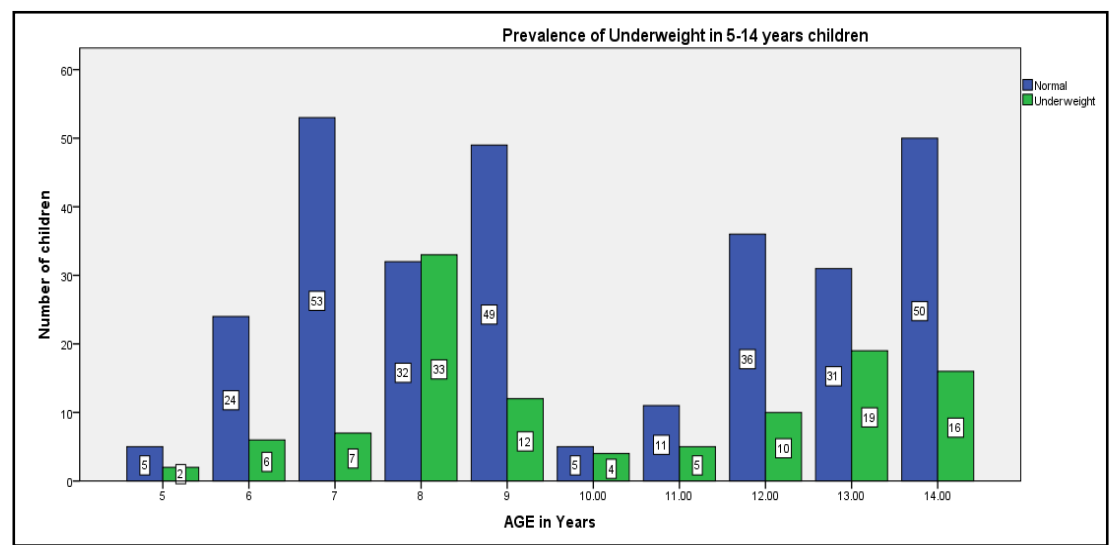

Fig. 1a: Distribution of Total study children according to Weight for Age $(n=410)$ 


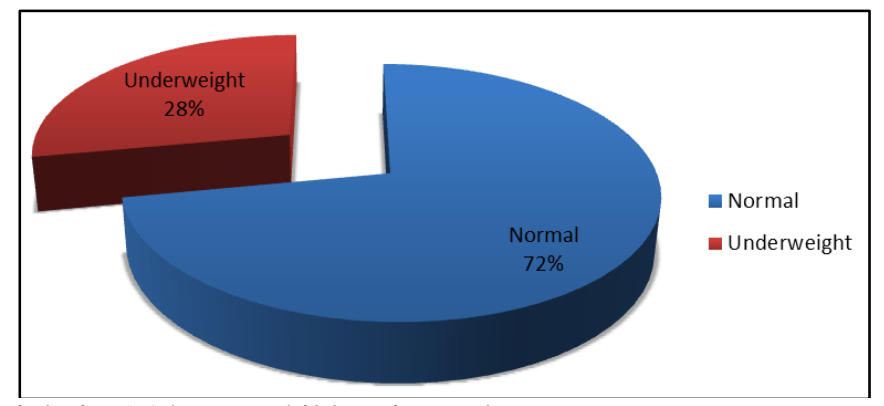

Fig. 1b: Prevalence of Underweight in 5-14 years children in rural Kanpur

Table 3a: Age-wise distribution of study children according to Height for Age

\begin{tabular}{|c|c|c|c|c|c|c|}
\hline \multirow{3}{*}{$\begin{array}{c}\text { Age (in } \\
\text { completed } \\
\text { yrs.) }\end{array}$} & \multicolumn{6}{|c|}{ Gender } \\
\hline & \multicolumn{2}{|c|}{ Male(n=218) } & \multicolumn{2}{|c|}{ Female $(n=192)$} & \multicolumn{2}{|c|}{ Total $(9 n=410)$} \\
\hline & $\begin{array}{c}\text { Normal Ht. } \\
( \pm \text { 2SD) N }(\%)\end{array}$ & $\begin{array}{c}\text { Stunting } \\
(-2 \mathrm{SD}) \mathbf{N}(\%)\end{array}$ & $\begin{array}{c}\text { Normal Ht. } \\
( \pm 2 \text { SD) N }(\%)\end{array}$ & $\begin{array}{c}\text { Stunting } \\
(-2 S D) \mathbf{N}(\%)\end{array}$ & $\begin{array}{c}\text { Normal Ht. } \\
( \pm 2 \text { SD) } \mathbf{N}(\%)\end{array}$ & $\begin{array}{c}\text { Stunting } \\
(-2 S D) \mathbf{N}(\%)\end{array}$ \\
\hline 5 & $2(50.0)$ & $2(50.0)$ & $1(33.3)$ & $2(66.7)$ & $3(42.9)$ & $4(57.1)$ \\
\hline 6 & $10(76.9)$ & $3(23.1)$ & $13(76.5)$ & $4(23.5)$ & $23(76.7)$ & $7(23.3)$ \\
\hline 7 & $28(93.3)$ & $2(6.7)$ & $25(83.3)$ & $5(16.7)$ & $53(88.3)$ & $7(11.7)$ \\
\hline 8 & $23(57.5)$ & $17(42.5)$ & $13(52.0)$ & $12(48.0)$ & $36(55.4)$ & $29(44.6)$ \\
\hline 9 & $21(72.4)$ & $8(27.6)$ & $25(78.1)$ & $7(21.9)$ & $46(75.4)$ & $15(24.6)$ \\
\hline 10 & $4(80.0)$ & $1(20.0)$ & $2(50.0)$ & $2(50.0)$ & $6(66.7)$ & $3(33.3)$ \\
\hline 11 & $5(83.3)$ & $1(16.7)$ & $9(90.0)$ & $1(10.0)$ & $14(87.5)$ & $2(12.5)$ \\
\hline 12 & $23(82.1)$ & $5(17.9)$ & $15(33.3)$ & $3(16.7)$ & $38(82.6)$ & $8(17.4)$ \\
\hline 13 & $15(75.0)$ & $5(25.0)$ & $28(93.3)$ & $2(6.7)$ & $43(86.0)$ & $7(14.0)$ \\
\hline 14 & $38(88.4)$ & $5(11.6)$ & $16(69.9)$ & $7(30.4)$ & $54(81.8)$ & $12(18.2)$ \\
\hline \multirow[t]{2}{*}{ Total } & $169(77.5)$ & $49(22.5)$ & $147(76.6)$ & $45(23.4)$ & $316(77.1)$ & $94(22.9)$ \\
\hline & \multicolumn{2}{|c|}{$\mathrm{X} 2=19.14 \mathrm{df}=9, \mathrm{p}=.024$} & \multicolumn{2}{|c|}{$\mathrm{X} 2=20.78 \mathrm{df}=9 \mathrm{p}=.014$} & \multicolumn{2}{|c|}{$\mathrm{X} 2=31.77 \mathrm{df}=9, \mathrm{P}=.001$} \\
\hline
\end{tabular}

Table 3a shows majority study boys of normal height were of 14 yrs age group while stunted boys(-2SD) were mostly of 8 and 9 years age group. Overall $22.5 \%$ boys were stunted. Majority of girls of age group 8 yrs and 9 yrs were found to be stunted. Overall $77.1 \%$ of study children were of normal height while stunted children were $22.9 \%$.

Table 3b: Distribution of study children according to Height for Age

\begin{tabular}{|c|c|c|c|}
\hline Height for Age $(\mathbf{c m})$ & $\mathbf{N}(\boldsymbol{\%})$ & Mean Height \pm 2 SD in cm. & Chi-square Test \\
\hline Normal HT $( \pm 2$ SD) & $316(77.1 \%)$ & $134.99 \pm 16.98$ & $\mathrm{P}=0.001$ \\
\hline Stunting $(<-2 \mathrm{SD})$ & $94(22.9 \%)$ & $116.79 \pm 16.40$ & \\
\hline
\end{tabular}

*Height for age Boys/Girls (WHO 2007 reference) ${ }^{14,15}$

Table 3b depicts height for age of normal Ht. children were of mean height $134.99 \pm 16.98 \mathrm{~cm}$. while mean height of stunted children was $116.79 \pm 16.40 \mathrm{~cm}$.

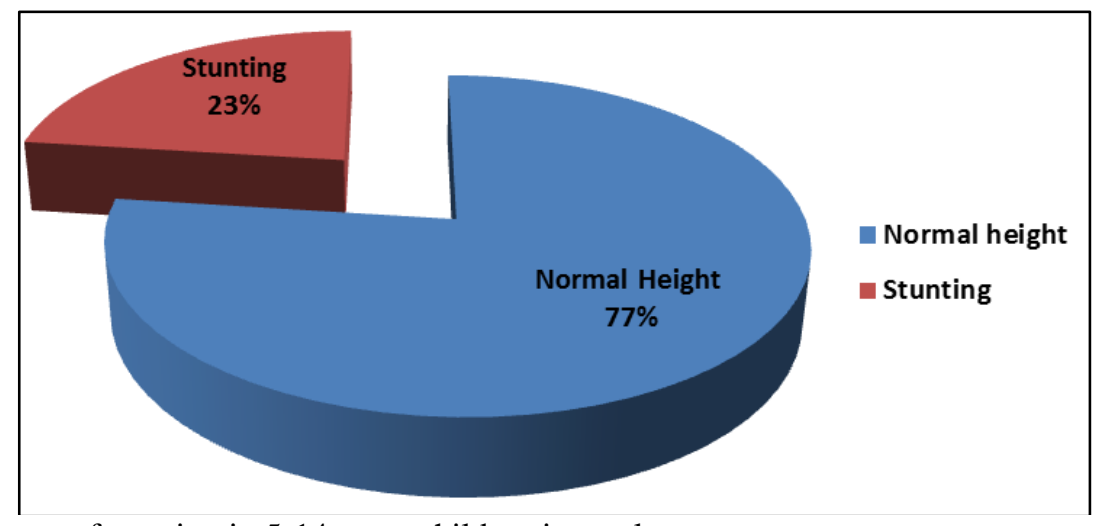

Fig. 2: Showing prevalence of stunting in 5-14 years children in rural areas 
Table 4a: Age-wise distribution of study children according to Body Mass Index for Age/Sex

\begin{tabular}{|c|c|c|c|c|c|c|}
\hline \multirow{3}{*}{$\begin{array}{c}\text { Age } \\
\text { (in yrs.) }\end{array}$} & \multicolumn{6}{|c|}{ Gender } \\
\hline & \multicolumn{2}{|c|}{ Male(n=218) } & \multicolumn{2}{|c|}{ Female $(n=192)$} & \multicolumn{2}{|c|}{ Total $(n=410)$} \\
\hline & $\begin{array}{c}\text { Normal } \\
\text { BMI } \\
\text { N }(\%)\end{array}$ & $\begin{array}{c}\text { BMI }(<-2 \text { SD }) \\
\text { Thinness } \\
\text { N }(\%)\end{array}$ & $\begin{array}{c}\text { Normal BMI } \\
\mathbf{N}(\%)\end{array}$ & $\begin{array}{c}\text { BMI }(<-2 S D) \\
\text { Thinness } \\
\text { N }(\%)\end{array}$ & $\begin{array}{c}\text { Normal } \\
\text { BMI } \\
\text { N }(\%)\end{array}$ & $\begin{array}{c}\text { BMI }(<-2 S D) \\
\text { Thinness } \\
\text { N }(\%)\end{array}$ \\
\hline 5 & $1(25.0)$ & $3(75.0)$ & $1(33.3)$ & $2(66.7)$ & $2(28.6)$ & $5(71.4)$ \\
\hline 6 & $8(61.5)$ & $5(38.5)$ & $14(82.4)$ & $3(17.6)$ & $22(73.3)$ & $7(26.7)$ \\
\hline 7 & $28(93.3)$ & $2(6.7)$ & $25(83.3)$ & $5(16.7)$ & $53(88.3)$ & $7(11.7)$ \\
\hline 8 & $28(70.0)$ & $12(30.0)$ & $11(44.0)$ & $14(56.0)$ & $39(60.0)$ & $26(40.0)$ \\
\hline 9 & $23(79.3)$ & $6(20.7)$ & $28(87.5)$ & $4(12.5)$ & $51(83.6)$ & $10(16.4)$ \\
\hline 10 & $3(60.0)$ & $2(40.0)$ & $3(75.0)$ & $1(25.0)$ & $6(66.7)$ & $3(33.3)$ \\
\hline 11 & $5(83.3)$ & $1(16.7)$ & $8(80.0)$ & $2(20.0)$ & $13(81.2)$ & $3(18.8)$ \\
\hline 12 & $25(89.3)$ & $3(10.7)$ & $14(77.8)$ & $4(22.2)$ & $39(84.8)$ & $7(15.2)$ \\
\hline 13 & $18(90.0)$ & $2(10.0)$ & $21(70.0)$ & $9(30.0)$ & $39(78.0)$ & $11(22.0)$ \\
\hline 14 & $37(86.0)$ & $6(14.0)$ & $19(82.6$ & $4(17.4)$ & $56(64.8)$ & $10(15.2)$ \\
\hline \multirow[t]{2}{*}{ Total } & $169(77.5)$ & $49(22.5)$ & 147(76.6) & $54(23.4)$ & $320(78.0)$ & $90(22.0)$ \\
\hline & \multicolumn{2}{|c|}{$\mathrm{X} 2=21.74 \mathrm{df}=9, \mathrm{p}=.010$} & \multicolumn{2}{|c|}{$\mathrm{X} 2=21.18 \mathrm{df}=9 \mathrm{p}=.012$} & \multicolumn{2}{|c|}{$\mathrm{X} 2=31.33 \mathrm{df}=9, \mathrm{P}=.001$} \\
\hline
\end{tabular}

Table 4a shows BMI<-2SD (Thinness) were found mostly among 8yrs (12/49) and 9 yrs (6/49) boys. BMI <-2SD (Thinness) in girls, were found mostly in 8year (14/54) and 13 year (9/54). Overall children with BMI<-2SD (Thinness) were 22\%.

Table 4b: Distribution of study children according to Body Mass Index for Age/Sex

\begin{tabular}{|c|c|c|c|}
\hline BMI for Age/Sex & N $(\%)$ & Mean BMI $\pm 2 S D$ & Chi-square Test \\
\hline Normal ( \pm 2 SD) & $320(78.0 \%)$ & $16.28 \pm 2.26$ & $\mathrm{P}=0.001$ \\
\hline BMI (<-2 SD) (Thinness) & $90(22.0 \%)$ & $13.03 \pm 0.92$ & \\
\hline
\end{tabular}

Table $4 \mathrm{~b}$ depicts Mean of normal BMI \pm 2 SD of children for age/sex were $16.28 \pm 2.26$ while children of BMI $(<-2$ SD)(Thinness) were $13.03 \pm 0.92$.

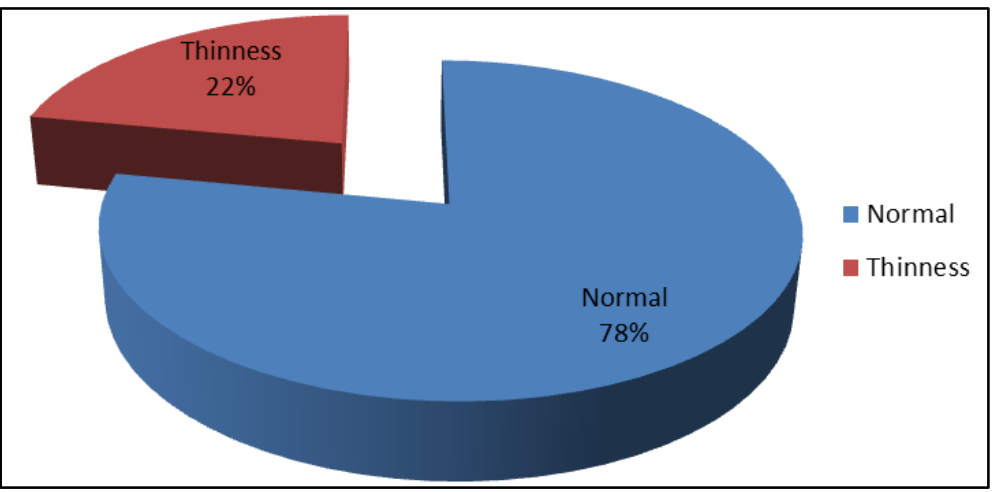

Fig. 3: Prevalence of Thinness (BMI <-2SD) in Rural areas of Kanpur

\section{Discussion}

Present study was undertaken amongst children of age 5 to 14 years residing in rural areas of Kanpur. This Age period is a changing phase of life, from growing childhood period to adolescent. Mean age of boys and girls were 10.546 \pm 2.66 years and $9.94 \pm 2.68$ years respectively (Table 1). Mean weight for age of normal Weight children Vs underweight children were $30.95 \pm 8.37 \mathrm{Kg}$ and19.61 $\pm 3.613 \mathrm{Kg}$ respectively.(Table 2a) Amruth $\mathrm{M}$ et al (2015) study found similar prevalence of underweight children but malnutrition among boys were more than girls. Result is different from the present study. ${ }^{16}$ Education of parents has positive effect on Weight for Age of children. Majority of children of illiterate parents were underweight for age viz. Father $37.2 \%$ Mother $39.9 \%$. This difference is found to be statistically significant $(p<0.05)$. Similar effect was observed by Ghosh J. et al study. ${ }^{17}$ Percentage of underweight children were found gradually increasing from upper to lower class viz. Upper/Upper Middle7.7\%;Middle 18.7\%,Lower Middle 26.7\%; Lower 35.6\%. This difference is found to be statistically significant $(\mathrm{X} 2=10.284 \mathrm{p}=0.016)$. Under weight children were found more in Joint Family $35 \%$ than Nuclear Family $19.7 \%$. This difference is found to be statistically significant $(\mathrm{p}<0.05$. (Table $2 \mathrm{a})$. Ajit Kumar Dey et al study $(2015)^{18}$ observed similar finding viz. undernourished children were more in Joint and Illiterate 
family. Education status of Parents particularly had a positive impact on nutritional status of children.

In present study, prevalence of underweight for age girls $(30.7 \%)$ was more than boys $(25.2 \%)$ and no child was belonging to overweight or obese category. Overall prevalence of underweight children was $27.8 \%$. This difference is found to be statistically significant. $(\mathrm{X} 2=28.583 \mathrm{df}=9, \mathrm{P}=.001)$ (Table 2b, Fig. 1). Findings are different from Shivaprakash N et al (2014) ${ }^{19}$ and Dey AK et al study(2015)[18] except age 14 and 15yrs where mean height and weight of boys were exceeded than girls.Findings are different from present study. Ghosh J. et al study ${ }^{17}$ also reported that prevalence of underweight as $38.65 \%$.

Overall stunted children were $22.9 \%$. This difference is found to be statistically significant $(\mathrm{X} 2=31.77 \mathrm{df}=9$, $\mathrm{P}=.001$ )[Table 3a, Fig. 2]. Mean height for age of children were normal and stunted children were $134.99 \pm 16.98 \mathrm{~cm}$ and $16.79 \pm 16.40 \mathrm{~cm}$ respectively [Table $2 \mathrm{~b}$ ]. The study conducted by Amruth $\mathrm{M}$ et al, ${ }^{16}$ Ghosh $\mathrm{J}$ et al ${ }^{17}$ found almost similar prevalence of stunting children but prevalence of malnutrition was more in boys than girls. Mandal S et $\mathrm{al}(2014)^{20}$ study found prevalence of stunting $40 \%$, this is different from our study.

Children with BMI<-2SD (Thinness) was found in $22 \%$. This difference is found to be statistically significant $(\mathrm{X} 2=31.33 \mathrm{df}=9, \mathrm{P}=.001)$. [Table 4a, Fig. 3]. Mean $\mathrm{BMI} \pm 2 \mathrm{SD}$ of children having normal $\mathrm{BMI}$ for age/sex were $16.28 \pm 2.26$ while children of BMI $(<-2 \mathrm{SD})$ (Thinness) were having mean BMI 13.03 \pm 0.92 . [Table $4 \mathrm{~b}$ ]

Similar study conducted by Gupta M et al $(2015)^{21}$ found $51.1 \%$ were undernourished and $48.9 \%$ were having normal nutritional status according to z-score of BMI for age. No child was belonging to overweight or obese category and $26.8 \%$ were thin. It was found that proportion of undernourished children was evenly distributed throughout the age group of 6-15 years and it was significantly higher in boys. Fazili A et al $(2012)^{22}$ study reported overall prevalence of thinness as $29.0 \%$, also they did not find any significant difference between males and females. Mandal S et al study $(2014)^{20}$ found among 5-14 years aged children, $48 \%$ showed thinness. Finding was different from our study.

\section{Conclusion}

Current study on nutritional assessment was conducted among children of 5-14 years in the covered rural areas of Kanpur. Mean age with standard deviation of boys and girls were respectively $10.55 \pm 2.66$ years and $9.94 \pm 2.68$ years. Mean weight for age of normal Weight and under weight children were $30.95 \pm 8.37 \mathrm{Kg}$ and $19.61 \pm 3.61 \mathrm{Kg}$ respectively. Education of parents has positive effect on Weight for Age of children. Majority of underweight for age children were of illiterate parents (Father 37.2\%, Mother $39.9 \%$ ), lower class family (35.6\%) and Joint Family 35\%. Underweight for Age of boys and girls were mostly of $8 \mathrm{yrs}$. age group viz. $47.5 \%$ and $56.0 \%$ respectively. Underweight girls were also of 13 years age (43.3\%).

The study shows undernourished children were found to be significantly associated with age, sex and education of the parents, socioeconomic class of the family and type of the family. It was significantly higher in females, age of puberty, children of uneducated mothers or of lower class family or belonging to joint family. Majority of underweight/stunted/thinness (BMI<-2SD) was found in children of 8 and 9 years of age group.

Present study shows overall prevalence of underweight, stunting and thinness (BMI<-2SD) for age/sex among children were $27.8 \%, 22.9 \%$ and $22 \%$ respectively. Study also concluded that prevalence of under nutrition was found to be higher among females as compared to males, according to weight for age, height for age and BMI <-2SD. This may be due to gender indiscrimination, seen more in rural areas. It is seen that growth spurt starts earlier in females than males. So there is extra caloric demand in girls, if it is not fulfilled, may result in under nutrition.

\section{Recommendation}

Inspite of running number of nutritional programme, robust mid-day meal programme, undernutrition is still prevalent among children. Emphasis should be paid to correct the loop holes of the running program. There is need of regular nutritional assessment of children at frequent intervals in school and at community level. Health education should be added in the school curriculum and it is needed to raise the maternal literacy particularly related to health care seeking behavior and attitude towards children health care.

\section{Source of Funding}

None.

\section{Conflict of Interest}

None.

\section{References}

1. Walker, [edited by] Christopher Duggan, John B. Watkins, W. Allan (2008). Nutrition in pediatrics: basic science, clinical application. Hamilton: BC Decker. pp. 127-141. ISBN 978-155009-361-2.

2. Manary, Mark J; Indi Trehan, Hayley S. Goldbach, Lacey N. LaGrone, Guthrie J. Meuli, Richard J. Wang, et al. "Antibiotics as Part of the Management of Severe Acute Malnutrition" Engl $J$ Med 2013;368(5):425-35.

doi:10.1056/NEJMoa1202851. PMC 3654668 PMID 2336349

6 The addition of antibiotics to therapeutic regimens for uncomplicated severe acute malnutrition was associated with a significant improvement in recovery and mortality rates.

3. Prüss-Üstün A, Bos R, Gore F, Bartram J. Safer water, better health - Costs, benefits and sustainability of interventions to protect and promote health. World Health Organization (WHO), Geneva, Switzerland. 2008

4. Bhutta Z. A, Ahmed T; Black R. E; Cousens S; Dewey K; Giugliani E et al. Maternal Child Undernutrition Study Group. "What works? Interventions for maternal and child undernutrition and survival". Lancet 2008;371(9610):41740. doi:10.1016/S0140-6736(07)61693-6. PMID 18206226.

5. "Global hunger declining, but still unacceptably high International hunger targets difficult to reach" (PDF). Food and Agriculture Organization of the United Nations. September 2010. Retrieved July 1, 2014.

6. Liz Young. World Hunger Routledge Introductions to Development. p. 20. ISBN 2002;978-1-134-77494-4. 
7. Waterlow IC, Buzina R, Keller W, Lane IM, Nichaman MZ, Tanner IM et al. The presentation and use of height and weight data for comparing the nutritional status of groups of children under the age of 10 years. Bull World Health Organ 1977;55:489-98. [PMC free article] [PubMed]

8. Kuczmarski RJ, Ogden CL, Guo SS, Grummer-Strawn LM, Flegal KM, Mei Z. et al. 2000 CDC Growth Charts for the United States: methods and development. Vital Health Stat. 2002;11(246):1-190. [PubMed]

9. WHO Expert Committee on Physical Status. Physical status: the use and interpretation of anthropometry, report of a WHO expert committee. Geneva, World Health Organization. 1995. (WHO Technical Report Series, No. 854; [http://whqlibdoc.who.int/trs/WHO_TRS_854.pdf, accessed 20 May 2011) [PubMed]

10. Adam Wagstaff; Naoke Watanabe (November 1999). "Socioeconomic Inequalities in Child Malnutrition in the Developing World". World Bank Policy Research Working Paper No. 2434. SSRN 632505. Missing or empty |url= (help)

11. International Institute of Population Sciences (IIPS). National Family Health Sur (NFHS-4); 2015-2016. Available at: http://www.rchiips.org/nfhs. Accessed on 14 June 2017

12. Lozano R, Naghavi M, Foreman K. "Global and regional mortality from 235 causes of death for 20 age groups in 1990 and 2010: a systematic analysis for the Global Burden of Disease Study 2010". Lancet 2012;380(9859): 2095128. doi:10.1016/S0140-6736(12)617280. hdl:10536/DRO/DU:30050819. PMID 23245604

13. 13.Measuring a child's growth. Geneva: World Health Organization. c2014 - [2014 Oct 26]. Available from:http://www.who.int/childgrowth/training/en/.

14. Onis M de, Onyango AW, Borghi E, Siyam A, Nishidaa C, Siekmann J et al. Development of a WHO growth reference for school-aged children and adolescents. WHO Bull 2007; 85: 660-7.

15. WHO AnthroPlus for Personal Computers Manual. Geneva: Department of Nutrition for Health and Development. c2009 [Cited 2014Sep 8]. Available from:http://www.who.int/growthref/tools/who_anthroplus_man ual.pdf.

16. Amruth M, Kumar S, Kulkarni AG, Kamble SV, Ismail IM. A study on nutritional status and morbidity pattern among primary school children in Sullia town, South India. Indian $J$ Basic Appl Med Res 2015;4,(4);100-12. www.ijbamr.com P ISSN: 2250-284X, E ISSN: 2250-2858

17. Ghosh J, Pati RR. Assessment of nutritional status among Santal-Munda tribal children in rural area of Amdanga block, North 24th Parganas District of West Bengal, India. Int J Curr Microbiol App Sci 2015;4(7):810-4

18. 18. Ajit Kumar Dey, Ajoy Bhusan Nath. Nutritional Status of School going Children (6-15 years) in a semi-urban area of Cachar district, Assam. J Evol Med Dent Sci 2017;6(54)405762. /eISSN- 2278-4802, pISSN- 2278-4748. DOI: $10.14260 / \mathrm{Jemds} / 2017 / 877$ at: https://www.researchgate.net/publication/319065060

19. N C Shivaprakash, Ranjit Baby Joseph. Nutritional Status of Rural School-Going Children (6-12 Years) of Mandya District, Karnataka. Int J Sci Stud 2014;2(2):39-43.

20. Mandal S, Prabhakar VR, Pal J, Parthasarathi R, Biswas R. An assessment of nutritional status of children aged 0-14 years in a slum area of Kolkata. Int J Med Public Health 2014;4:159-62.

21. Gupta M, Borle A, Chhari N, Gupta S. Nutritional Status Assessment using WHO z-scores (BMI for Age) in Children Aged 6-15 years - A Study from Central India. Natl $J$ Community Med 2015;6(1):92-7.

22. Fazili A, Mir AA, Pandit IM, et al. Nutritional status of school age children (5-14 years) in a rural health block of North India (Kashmir) Using WHO Z-Score System. Online J Health Allied Scs 2012;11(2):1-3.

How to cite this article: Nath S, Gahlot A, Sinha PK, Nath M. Assessment of nutritional status of children of age 5-14 years in covered rural area of Private Medical College, Kanpur. Indian J Forensic Community Med 2019;6(3):163-9. 